\title{
A hazai sclerosis multiplex betegpopuláció életkori és nemi megoszlása 2004 és 2016 között
}

\author{
Iljicsov Anna dr. ${ }^{1}$ - Bereczki Dániel dr. ${ }^{1,2}$ - Dobi Balázs ${ }^{2,3}$ \\ Oberfrank Ferenc dr. ${ }^{4}$ - Bálint Mónika ${ }^{5}$ - Ajtay András dr. ${ }^{1,2}$ \\ Milanovich Dániel dr. ${ }^{1}$ - Simó Magdolna dr. ${ }^{1}$ \\ ${ }^{1}$ Semmelweis Egyetem, Általános Orvostudományi Kar, Neurológiai Klinika, Budapest \\ ${ }^{2}$ MTA-SE Neuroepidemiológiai Kutatócsoport - ELKH, Budapest \\ ${ }^{3}$ Eötvös Loránd Tudományegyetem, Valószínúségelméleti és Statisztika Tanszék, Budapest \\ ${ }^{4}$ Kísérleti Orvostudományi Kutatóintézet, Budapest \\ ${ }^{5}$ Közgazdaság- és Regionális Tudományi Kutatóközpont, Budapest
}

\begin{abstract}
Bevezetés: Mivel hazánkban a sclerosis multiplex gyakoriságáról, valamint életkori és nemi jellegzetességeiről az elmúlt évtizedekben - egészen 2020-ig - csak regionális jellegú felmérések készültek egy-egy centrum betegforgalma alapján, az újonnan diagnosztizált és már ismert betegek országos koreloszlásáról és annak idóbeli változásairól nincsenek ismereteink.

Célkitüzés: Jelen munkánkban több mint 14000 beteg adatainak elemzésével a prevalens és incidens betegek koreloszlásának változását vizsgáljuk 2004-2016 során, és eredményeinket összevetjük az elmúlt évtizedekben közölt hazai adatokkal.

Módszer: Munkacsoportunk az egészségbiztosítási pénztár anonimizált NEUROHUN adatbázisát elemezte, amely tartalmazza a 2004 és 2016 között az összes hazai, államilag finanszírozott, a fekvő- és járóbeteg-szakellátásból neurológiai diagnózissal jelentett esetet. A sclerosis multiplex BNO-kódjának elófordulása alapján korábban létrehoztuk a betegség adminisztratív definícióját, és megbecsültük a sclerosis multiplex országos prevalenciáját és incidenciáját. Eredmények: A prevalens betegek átlagéletkora 2015-ben 47,9 év, ugyanebben az évben az incidens betegek átlagéletkora 37,4 év volt. Vizsgálatunk szerint a prevalens betegek átlagéletkora szignifikánsan - évente egyötöd-egyharmad évvel $(\mathrm{p}<0,001)$ - emelkedik, mégpedig a nők esetében nagyobb mértékben. A nők átlagosan fél évvel idősebbek, mint a férfi páciensek (szignifikáns különbség: $\mathrm{p}=0,002$ ). A prevalens betegekben a legnépesebb korosztály az ötvenévesek felól a fiatalabb, 35-40 éves korosztály felé mozdul. Az incidens betegek átlagéletkora lassan, de szignifikánsan - évente átlagosan egyharmad évvel $(\mathrm{p}<0,001)$ - csökken.

Következtetés: Eredményeink szerint az újonnan diagnosztizált sclerosis multiplexes páciensek átlagosan egyre fiatalabbak, és a prevalens betegek között is egyre fiatalabb korosztályok a legnépesebbek, de a javuló túlélés és a hosszabb élettartam miatt a prevalens betegek átlagéletkora összességében valószínúleg fokozatosan emelkedik.

Orv Hetil. 2021; 162(19): 746-753.
\end{abstract}

Kulcsszavak: sclerosis multiplex, prevalencia, incidencia, koreloszlás, nemi eloszlás, adatbázis

\section{Age and gender characteristics of patients affected with multiple sclerosis in Hungary between 2004 and 2016}

Introduction: The nationwide age and gender distribution of newly diagnosed and prevalent multiple sclerosis patients has been unknown in Hungary, as until 2020 only regional studies had been reported about the frequency and age characteristics of subjects with multiple sclerosis, based on single-center patient registries.

Objective: In the present study with the analysis of over 14000 patients, we describe the changes in age distribution of prevalent and incident subjects between 2004 and 2016 and compare our results with the data published on the subject during the last decades in Hungary.

Method: We have analyzed the pseudonymized NEUROHUN database provided by the single-payer National Health Insurance Fund, that contains each claim submitted by public hospitals and outpatient services for neurologic diseases between 2004 and 2016. Using the ICD10-code of multiple sclerosis, we have previously established the administrative definition of the illness and estimated its prevalence and incidence in the country. 
Results: The mean age of prevalent patients was 47.9 years in 2015 , whereas in the same year the mean age of incident cases was 37.4 years. The average age of prevalent patients shows a significant rise - with an annual increase of one fifth-one third year $(\mathrm{p}<0.001)$ - with a more pronounced increase among women. The age of women is higher by half a year $(\mathrm{p}=0.002)$. The most populous age groups among prevalent subjects shift from the fifties towards the younger generations between 35-40 years of age. The average age of incident subjects slowly, but significantly decreases, with a mean annual decrease of about one third year $(\mathrm{p}<0.001)$.

Conclusion: Our results suggest that though new patients are younger year-by-year and the most populous age groups are also younger, altogether the average age of prevalent subjects continuously increases, probably due to the longer survival and lifespan of patients with multiple sclerosis.

Keywords: multiple sclerosis, prevalence, incidence, age and gender distribution, database

Iljicsov A, Bereczki D, Dobi B, Oberfrank F, Bálint M, Ajtay A, Milanovich D, Simó M. [Age and gender characteristics of patients affected with multiple sclerosis in Hungary between 2004 and 2016]. Orv Hetil. 2021; 162(19): 746-753

(Beérkezett: 2020. október 12.; elfogadva: 2020. november 24.)

\section{Rövidítések}

BNO = Betegségek Nemzetközi Osztályozása $;$ EDSS $=($ Expanded Disability Status Scale) Bővített Rokkantsági Állapot Skála; ICD10 $=($ International Classification of Diseases, 10th edition) BNO, 10. kiadás; NEUROHUN = a 2004 és 2016 között ideggyógyászati ellátásban részesült valamennyi beteg elemezhető és kutatható, anonimizált adatait tartalmazó adatbázis; NKP = Nemzeti Kiválósági Program; OENO = Orvosi Eljárások Nemzetközi Osztályozása; OEP = Országos Egészségbiztosítási Pénztár (ma Nemzeti Egészségbiztosítási Alapkezelő); taj = társadalombiztosítási azonosító jel

A sclerosis multiplex a központi idegrendszer krónikus, autoimmun eredetû megbetegedése, amelynek során demyelinisatio és axonpusztulás lép fel, így fizikális, kognitív és pszichés tünetekkel jár. Ezek akár jelentôsen és véglegesen csökkenthetik a beteg mozgáskészségét, életminőségét, valamint produktivitását is. Korszerú gyógyszeres kezeléssel a betegek egy része akár évekig-évtizedekig tünetmentes vagy tünetszegény állapotban tartható, e készítmények azonban igen költségesek. Emellett - mivel a fiatal felnőtt kori rokkantságnak a traumás eredetủ sérülés után ez a második leggyakoribb oka [1] - a kieső munkaerő, a betegek komplex kezelése és gondozása, esetleges otthoni vagy intézeti ápolása mind jelentős társadalmi és gazdasági ráfordítást igényel $[2,3]$. Mindezek alapján indokolt minél pontosabb adatokat szerezni a betegek számáról és korösszetételéről, hogy a szükséges erőforrások allokációja optimalizálható legyen.

Magyarországon évtizedekig csak regionális felmérések készültek a sclerosis multiplex gyakoriságáról [4-12], amelyek mind egy-egy sclerosis multiplex gondozócentrum betegforgalmának elemzésén alapultak. Mivel jelenleg még nem létezik egységes, országos betegregiszter, vizsgálatunkhoz a 2004 és 2016 közötti időszak egészségbiztosítási pénztári anonimizált adatait használtuk fel.
Kutatásunk célkitűzése az volt, hogy felmérjük a hazánkban sclerosis multiplexszel élő betegek koreloszlását, illetve megbecsüljük ennek változásait.

$\mathrm{Az}$ egészségügyi adminisztratív adatok elemzésével dolgozó epidemiológiai vizsgálatok a sclerosis multiplex vonatkozásában is egyre gyakoribbá váltak az elmúlt években [13-16]. A módszer előnyei közé tartozik, hogy a felhasznált adatok nagy populációra vonatkoznak, könnyen feldolgozhatók, standardizáltak, és a kivitelezés költséghatékony. Hátránya lehet, hogy az adatok minősége olykor szuboptimális vagy hiányos (hiszen rögzítésük eredeti célja adminisztratív és nem tudományos jellegú volt), valamint az egyes betegekre vonatkozóan kevés egyedi klinikai információ nyerhető (a sclerosis multiplex esetében például a kórlefolyás formáját, a betegség aktivitását és a beteg állapotát érdemben megítélni nem lehet).

A jelen dolgozatban összefoglaljuk az elmúlt évtizedekben megjelent, a sclerosis multiplex hazai epidemiológiájáról szóló közleményeket és azok eredményei alapján a betegek életkori jellemzőit Magyarországon. Adatbázisunkat elemezve vizsgáljuk az adott évben élő (prevalens) sclerosis multiplex betegek átlagéletkorát és koreloszlását, valamint az adott évben újonnan diagnosztizált (incidens) betegek átlagéletkorát és annak változását.

\section{Módszerek}

A kutatás számára az Országos Egészségbiztosítási Pénztár (OEP, ma Nemzeti Egészségbiztosítási Alapkezelő) szolgáltatta az általa finanszírozott - tehát az összes hazai állami kórház és szakrendelő, valamint a szerződött magánellátók által nyújtott - egészségügyi ellátások adatait. Ez az adatbázis tartalmazza többek között a beteg nemét, születési évét, lakhelye irányítószámát, az ellátásra vonatkozóan pedig annak dátuma, a szolgáltató inté- 
zet és a szakmakód, a kódolt beavatkozások OENO- és a diagnózisok BNO-kódja szerepel. A kórházi bennfekvések esetén az összes kódolt BNO-kód és azok jellege (elsődleges vagy másodlagos diagnózis, szövődmény, kísérő betegség, halálok), míg a járóbeteg-ellátásban csak a fődiagnózis található meg. Az elemzendő NEUROHUN adatbázis betegei anonimizáltak: a betegek nevét és tajszámát alfanumerikus kód helyettesíti, ezzel biztosítva az anonimitást és az adatbázison belüli követés lehetőségét. A halálozás évét a Központi Statisztikai Hivatal nyújtotta. Megjegyezzük, hogy a háziorvosi alapellátás megjelenéseit ez az adatbázis nem tartalmazza.

Vizsgálatunkhoz az OEP-tól azoknak a személyeknek kértük le a fenti egészségügyi ellátási adatait, akik 2004. január 1. és 2016. december 31. között legalább egy alkalommal kapták az alábbi diagnózisok (BNO-kód) egyikét: neurológiai (G00-G99) vagy cerebrovascularis (I60-I69) betegségek; az agyhártyák és a központi idegrendszer jóindulatú, rosszindulatú vagy bizonytalan viselkedésű daganatai (D32-33, D42-43, C69-72); illetve néhány aspecifikus neurológiai panasz, úgymint fejájás (R51), fájdalom (R52), rossz közérzet és fáradtság (R53), syncope és collapsus (R55), egyéb és nem meghatározott görcsök (R56). Ez az adatbázis 4,29 millió személy betegútját tartalmazza. Közülük kiszürtük azokat, akik legalább egy alkalommal megkapták a sclerosis multiplex BNO-kódját (G35), így létrehozva a „sclerosis multiplex adatbázist”, amely közel 34400 beteg anonimizált adatait tartalmazza.

Mivel ez a szûrés nem eléggé specifikus - hiszen olyanok is szerepelnek benne, akik például egyetlen laborvizsgálathoz kaptak sclerosis multiplex diagnózisú kódot -, a nemzetközi példákat - elsősorban Marrie [13] és Culpepper munkásságát [17, 18] - alapul véve és adaptálva létrehoztuk a sclerosis multiplex „adminisztratív definícióját" [19]. E szerint azt a személyt tekintjük sclerosis multiplexesnek, aki az alábbi három kritérium mindegyikét teljesíti a vizsgált időszakban:

- legalább három különböző dátummal kapott G35-ös diagnóziskódot (akár elsődleges, akár kísérő betegségként, fekvő vagy járó betegként), de nem véve figyelembe a laboratóriumi, képalkotó és patológiai vizsgálatok során adott diagnózisokat, mivel azok gyakran csak iránydiagnózisok;

- a diagnózis megerósítésének tekintettük, hogy a beteghez regisztrált G35-ös kódok legalább egyikét neurológus adta, azaz neurológiai osztályos bennfekvés során vagy neurológiai jellegú szakrendelésen rögzítették;

- a G35-ös kódokat legalább két különböző (nem feltétlenül egymást követő) naptári évben kapta a beteg, ezzel igyekezve kiszürni azokat, akiket sclerosis multiplex irányában vizsgáltak, és végül ez a diagnózis nem igazolódott.

A fenti esetdefiníciót saját betegpopuláció, illetve virtuális „valódi negatív” esetcsoport segítségével validáltuk [19], ez alapján a kritériumrendszer specificitása és szenzitivitása is elérte a 99\%-ot. A definíció meghatározásakor tudatosan törekedtünk a minél magasabb specificitásra, hogy így minél kisebb legyen a tévesen sclerosis multiplex betegként azonosítottak aránya, vállalva ezzel a valódi betegszám alulbecslésének lehetőségét. A kritériumokat a 2004 és 2016 közti 13 évben összesen több mint 14400 személy teljesítette, a továbbiakban őket tartottuk sclerosis multiplexes betegnek.

$\mathrm{Az}$ adott személyhez rögzített G35-ös BNO-kódok közül az adatbázisban történő első megjelenés időpontját tekintettük a betegség diagnosztizálásának, tehát a páciens ebben az évben jelent meg incidens esetként. Az adott év prevalens esetszámát úgy származtattuk, hogy az előző évi prevalens esetekből kivontuk az elhunytak számát, és hozzáadtuk az új (incidens) betegek számát. A nyers incidenciát és prevalenciát 100000 före vonatkoztattuk nők, férfiak és mindkét nem esetében, a 2011. évi hazai népszámlálás adatait [20] használva.

Mivel az adatbázis csak 2004-tôl tartalmazza az egészségügyi adatokat, az első években az incidens esetek egy része (2004-ben pedig nagy többsége) a valóságban nem újonnan diagnosztizált beteg, hanem olyan, aki 2004 előtt már ismert, sclerosis multiplexszel élő beteg volt, csak 2004-től kezdve az adott évben kapott először ezzel az indokkal egészségügyi ellátást. Emiatt az adatbázis első 3 évének adatait az incidencia értékelésekor nem vettük figyelembe. Hasonlóképpen, mivel az egyik kritériumunk szerint a sclerosis multiplex diagnózisához előírtuk, hogy a beteg minimum 2 naptári évben kapjon G35-ös kódot, az utolsó néhány év incidenciamutatója alulbecsli a valós sclerosis multiplex betegek számát, és 2016-ra nem értelmezhető az incidencia. Adataink ezen metodikai korlátok figyelembevételével értékelendők.

\section{Eredmények}

\section{A prevalens betegek átlagéletkora, koreloszlása}

Az alkalmazott többszörös lineáris regressziós modellben vizsgáltuk, hogy az eltelt évek és a nem interakcióban milyen hatással van a prevalens betegek életkorára. A 1. táblázatban látható eredmények szerint a prevalens férfi betegek átlagéletkora minden évben nagyjából 0,22 évnyit nő (szignifikáns növekedés: $\mathrm{p}<0,001$ ), ezenfelül a nők esetében 0,1 évvel többet nő az átlagéletkor évente, mint a férfiaknál (szignifikáns eltérés: $p<0,001$ ). A modell szerint emellett a nők átlagosan fél évvel idősebbek, mint a férfi páciensek (szignifikáns különbség: $\mathrm{p}$ = $0,002)$. A Shapiro-Wilk-teszt nem mutatott problémát a modell illeszkedésével kapcsolatban $(\mathrm{p}=0,265)$.

A prevalens betegek koreloszlása a lineáris trendeken felül is mutat kisebb változásokat a vizsgált időszakban: ötéves korcsoportokat alkotva a legnépesebb korcsoport 2009-ig az 50-54 éves korosztályba esik, a 2010. és a 2011. évben a 40-44 éves korcsoportban van a legtöbb beteg, míg 2012-től a 35-39 éves korcsoport a legnépesebb. Mindezt jól követi az adott évi prevalens betegek 
1. táblázat $\mid$ Az adott évben élő (prevalens) és újonnan diagnosztizált (incidens) sclerosis multiplexes betegek átlagéletkora

\begin{tabular}{|c|c|c|c|c|c|c|}
\hline \multirow[t]{2}{*}{ Év } & \multicolumn{3}{|c|}{$\begin{array}{l}\text { A prevalens betegek } \\
\text { átlagéletkora (év) }\end{array}$} & \multicolumn{3}{|c|}{$\begin{array}{c}\text { Az incidens betegek } \\
\text { átlagéletkora (év) }\end{array}$} \\
\hline & Férfiak & Nők & Együtt & Férfiak & Nók & Együtt \\
\hline 2004 & 44,29 & 45,05 & 44,84 & 44,29 & 45,05 & 44,84 \\
\hline 2005 & 44,65 & 45,41 & 45,20 & 42,10 & 42,75 & 42,56 \\
\hline 2006 & 45,00 & 45,69 & 45,50 & 41,98 & 41,13 & 41,37 \\
\hline 2007 & 45,18 & 45,97 & 45,75 & 39,90 & 40,56 & 40,37 \\
\hline 2008 & 45,51 & 46,24 & 46,04 & 40,15 & 39,31 & 39,54 \\
\hline 2009 & 45,54 & 46,56 & 46,28 & 37,38 & 39,26 & 38,68 \\
\hline 2010 & 45,66 & 46,78 & 46,47 & 36,68 & 37,63 & 37,35 \\
\hline 2011 & 46,07 & 47,13 & 46,83 & 40,04 & 38,51 & 38,98 \\
\hline 2012 & 46,08 & 47,46 & 47,05 & 36,24 & 38,02 & 37,46 \\
\hline 2013 & 46,24 & 47,74 & 47,33 & 36,92 & 38,20 & 37,80 \\
\hline 2014 & 46,45 & 48,06 & 47,61 & 37,44 & 37,68 & 37,60 \\
\hline 2015 & 46,80 & 48,40 & 47,95 & 37,21 & 37,54 & 37,44 \\
\hline 2016 & 47,39 & 49,17 & 48,68 & na & na & na \\
\hline p-érték & \multicolumn{2}{|c|}{$\begin{array}{c}\text { Nemi különbség: } \\
0,002^{*}\end{array}$} & $\begin{array}{l}\text { Növeke- } \\
\text { dés: } \\
\text { Férfiak: } \\
<0,001^{*} \\
\text { Nók a } \\
\text { férfiak- } \\
\text { hoz } \\
\text { képest: } \\
<0,001^{*} \\
\text { Együtte- } \\
\text { sen: } \\
<0,001^{*}\end{array}$ & \multicolumn{2}{|c|}{$\begin{array}{c}\text { Nemi különbség: } \\
0,118\end{array}$} & $\begin{array}{l}\text { Növeke- } \\
\text { dés: } \\
\text { Együtte- } \\
\text { sen: } \\
<0,001^{*} \\
\text { (Nő́knél } \\
\text { nincs } \\
\text { különb- } \\
\text { ség a } \\
\text { férfiak- } \\
\text { hoz } \\
\text { képest) }\end{array}$ \\
\hline
\end{tabular}

Metodikai okokból a dőlt betús értékeket az elemzéskor nem vettük figyelembe, a magyarázatot lásd a szövegben. A p-értéket akkor tekintettük szignifikánsnak, ha kisebb volt, mint 0,05, és ezt csillaggal jelöltük.

na $=$ nincs adat

életkorának módusza (azaz a leggyakoribb életkorérték az adott évben, ötéves korcsoport nélkül), amely 2009 ig 50 és 55 év közé esik, majd 2010-től 35 és 40 év között mozog.

Az 1. ábra hisztogramokkal mutatja be az egyes években az adott életkorú férfi és női betegek arányát (tehát nem abszolút számát) a prevalens populációban, a fenti változások szemléltetésére. Jól látszik, hogy a görbék csúcsa (a legnagyobb arányú korosztály) lassan balra tolódik a 40-es életkor felé mind a nók, mind a férfiak esetében. Ugyanakkor megjegyzendő, hogy az idősebb, 70 év feletti korosztály is egyre nagyobb arányban képviselteti magát: például míg 2004-ben alig 0,5-0,5\% volt 70 éves a prevalens női és férfi betegek között, ez 2016-ra közel 1-1\%-ra emelkedett.

\section{Az incidens betegek átlagéletkora}

Az adott évi új betegek száma a bevezetőben említett metodikai korlátok miatt az első 3 évben kevésbé megbízható, így az elemzésekben csak a 2007-tól újonnan megjelent betegeket vettük figyelembe, lásd az 1. táblázatban. A többszörös lineáris regressziós modell alapján minden évvel egyharmad évnyit csökken az incidens betegek átlagéletkora (szignifikáns: $\mathrm{p}<0,001$ ). A nem hatása nem volt szignifikáns $(\mathrm{p}=0,118)$, vagyis a két nem között nincs ebben lényegi eltérés. A Shapiro-Wilk-teszt marginális problémát mutatott a modell illeszkedésével kapcsolatban ( $\mathrm{p}=0,044)$; ez leginkább csak a konfidencia-intervallumokat és a p-értéket befolyásolja, de tekintve, hogy az életkor hatása erôsen szignifikáns $(\mathrm{p}<0,001)$, ez nem változtat a következtetéseken.

\section{Megbeszélés}

Dolgozatunkban a magyarországi sclerosis multiplex betegek életkori jellegzetességeit vizsgáltuk a 2004 és 2016 közötti időszak országos szakellátási adatainak elemzésével. Hosszabb időperiódusra vonatkozóan három adattal írhatjuk le a sclerosis multiplexszel élő betegek életkori jellemzőit és azok változásait: az egy időpontban élő (prevalens) betegek életkora; az újonnan diagnosztizált (incidens) betegek életkora; illetve érdekes lehet elemezni a prevalens betegeknek a diagnózis megállapításakor betöltött életkorát. Adatbázisunk jellege miatt a prevalens betegek életkorát pontosan meg tudjuk adni. Az új esetek életkorának meghatározásakor a pontosság már kisebb, adatbázisunkban ugyanis az első megjelenés nem feltétlenül jelent újonnan diagnosztizált sclerosis multiplexet - ez különösen az adatbázis első 3-4 évében okozhat torzítást. A harmadik életkori jellemzőt - a prevalens betegek életkora a betegségük kezdetén - a 2004 előtti adatok hiánya miatt nem tudjuk megbízhatóan értékelni. Ezek miatt elemzésünkben a prevalens betegek életkorára mutatunk be pontos adatokat; az újonnan diagnosztizált (incidens) esetekre megbízható becslést adunk, viszont nem törekszünk a harmadik életkori paraméter vizsgálatára.

Hazánkban 2020-ig csak regionális felméréseken alapuló, egy centrum betegforgalmát vizsgáló közlemények [4-12] születtek a sclerosis multiplex elöfordulásának gyakoriságáról, amelyek fóbb eredményeit a 2. táblázatban foglaltuk össze. A fóvárosi Szent István Kórházban gondozott betegek számának alapján már az 1960-as években megjelent becslés a sclerosis multiplex hazai előfordulásáról [4], de a közlemény nem tér ki arra, hogy milyen kritériumok szerint állapították meg a kórismét. Később, az 1980-as években Baranya megye és Pécs [5, 6], 1994-ben Fejér megye egy-egy centrumkórházának betegforgalma és részletes betegkövetése alapján születtek regionális vonatkozású epidemiológiai vizsgálatok, amelyek már az aktuális nemzetközi diagnosztikai kritériumrendszert alkalmazták. Az előbbi külön kitért a 


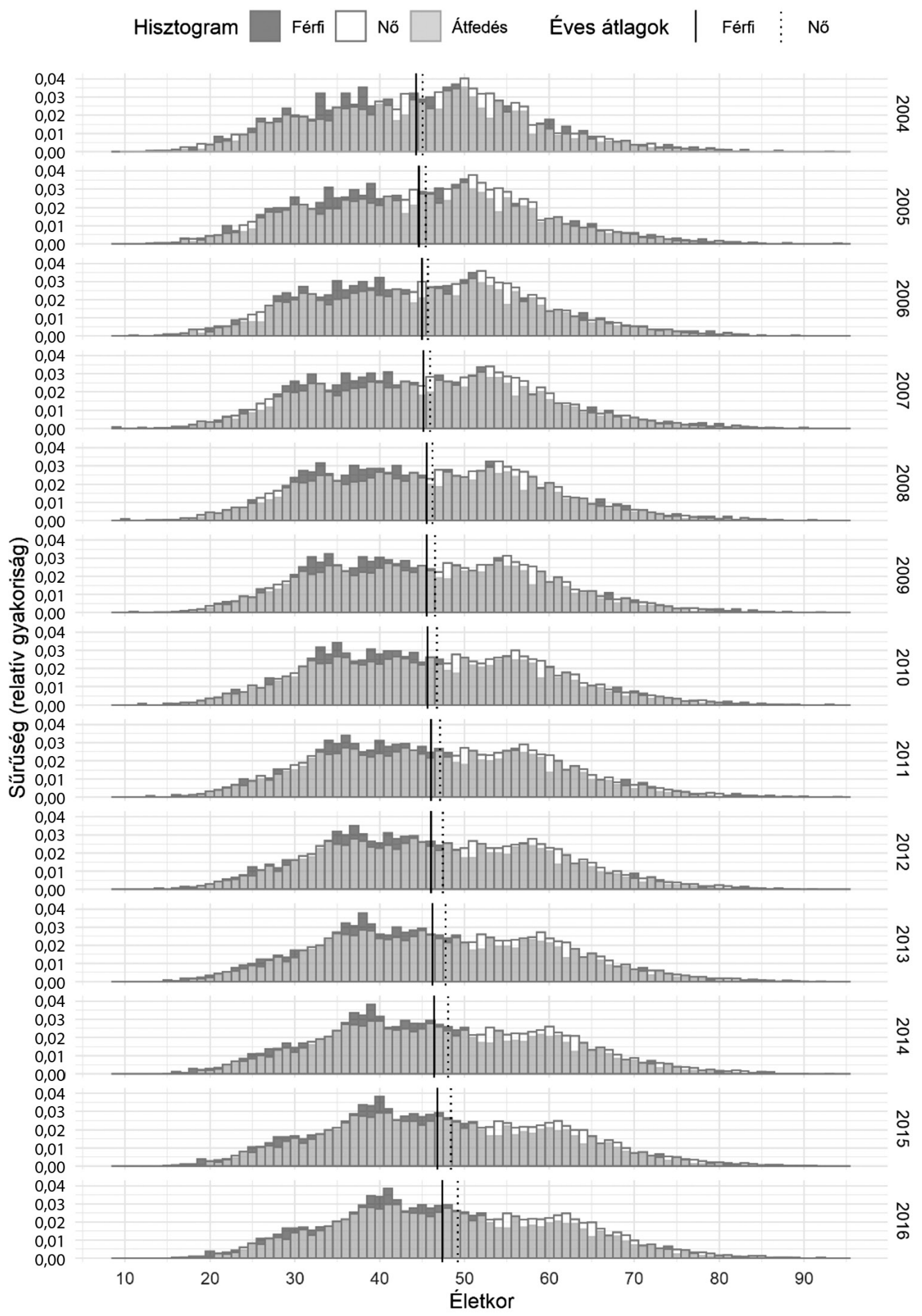

1. ábra $\quad$ A prevalens betegek között az adott életkorúak sűrúsége és átlagéletkora, férfi (sötétszürke) - nő (fehér) bontásban, évente Ábramagyarázat: az X-tengelyen: az egyes életkorok, években; az Y-tengelyen: az adott életkorú betegek súrúsége (relatív gyakorisága) az az évi, adott nemú, prevalens populációban. Az adott évi prevalens női, illetve férfi betegek átlagéletkorát függőleges folytonos és szaggatott vonallal jeleztük (években)

magyar és a roma populáció prevalenciabeli különbségeire [5]. Az utóbbi a pontprevalencia mellett többévnyi incidenciaadatot is közölt számítógépes betegnyilvántartásuk alapján [7], illetve vizsgálta a páciensek életkorát a diagnóziskor [8], továbbá megyén belüli megoszlását (például falu-város), foglalkozását is. Ezt követően, 1998-tól napjainkig csak Szeged és Csongrád megye epidemiológiai jellemzőiról születtek publikációk [9-12], a Szegedi Tudományegyetem Neurológiai Klinikája munkacsoportjának felmérése alapján. Ehhez a Klinikán 1993 óta vezetett sclerosis multiplex regiszter részletes adatait - beleértve a kórlefolyás típusát, a kezelést és a 
betegek állapotát is - elemezték, mindig a legfrissebb diagnosztikai kritériumokat felhasználva. Megjegyzendő, hogy a székesfehérvári sclerosis multiplex centrum betegnyilvántartása alapján 2003. december 31-én a pontprevalencia kiemelkedően magas, 170,6/100 000 volt a Poser-féle diagnosztikai kritériumok szerinti definitív sclerosis multiplexre vonatkozóan (Guseo A., szóbeli közlés, 2020. szeptember).

Az első olyan epidemiológiai vizsgálatban, amely a teljes hazai populációra vonatkozott [19], részletesen ismertettük az egészségbiztosító által nyújtott adminisztratív adatbázis feldolgozásának módszertanát. Adataink szerint a 2004 és 2016 közti 13 évben összesen 14437 személy teljesítette a sclerosis multiplex adminisztratív kritériumait. A vizsgált időszakban az éves prevalenciaér- tékek szignifikánsan növekedtek, akár a teljes populációt, akár a két nemet külön vizsgáltuk. Így 2015-re a sclerosis multiplex nyers prevalenciája 130,8/100 000 före emelkedett (a nók esetében 179,5/100 000, a férfiaknál 76,8/100 000 értékre). A nyers incidencia 2015-ben a teljes lakosságra számítva 5,4/100 000 volt (a nők körében 7,2/100 000, a férfiaknál 3,5/100 000). A prevalens esetekben a nő : férfi arány végig 2,6 maradt, míg az incidens esetekben ez 1,9-2,5 volt [19].

A 2. táblázatból is kitűnik, hogy hazánkban a sclerosis multiplex nyers prevalenciája az elmúlt 60 évben jelentősen emelkedett. Ezt a jelenséget már több országban leírták [21-26], és valószínúleg számos tényező közrejátszik benne: a javuló hozzáférés az egészségügyi ellátáshoz, a képalkotó és egyéb diagnosztikai eszközökhöz;

2. táblázat |A sclerosis multiplex magyarországi epidemiológiájának témájában született hazai közlemények összefoglalása

\begin{tabular}{|c|c|c|c|c|c|c|c|c|c|c|}
\hline Szerző & $\begin{array}{l}\text { Diagnoszti- } \\
\text { kai } \\
\text { kritérium- } \\
\text { rendszer }\end{array}$ & Jelleg & $\begin{array}{l}\text { Földrajzi- } \\
\text { lag }\end{array}$ & $\begin{array}{l}\text { A prevalencia } \\
\text { időpontja }\end{array}$ & $\begin{array}{l}\text { Nyers } \\
\text { preva- } \\
\text { lencia }\end{array}$ & $\begin{array}{l}\text { Nyers } \\
\text { prevalencia } \\
\mathrm{F}: \mathrm{N}\end{array}$ & $\begin{array}{l}\mathrm{F} \text { : N arány } \\
\text { prevalens } \\
\text { betegek } \\
\text { közt }\end{array}$ & $\begin{array}{l}\text { A prevalens } \\
\text { betegek } \\
\text { átlagéletkora } \\
\text { (év) }\end{array}$ & $\begin{array}{l}\text { A prevalens } \\
\text { betegek } \\
\text { átlagéletkora } \\
\text { a diagnózis- } \\
\text { kor (év) }\end{array}$ & Incidencia \\
\hline $\begin{array}{l}\text { Lehoczky } \\
{[4]}\end{array}$ & na & $\begin{array}{l}\text { Budapesti } \\
\text { kórház }\end{array}$ & $\begin{array}{l}\text { Magyar- } \\
\text { országra } \\
\text { vetítve }\end{array}$ & 1961 & 20 & na & na & na & na & na \\
\hline Pálffy [5] & Bauer & $\begin{array}{l}\text { Egyetemi } \\
\text { neurológiai } \\
\text { klinika }\end{array}$ & $\begin{array}{l}\text { Baranya } \\
\text { megye }\end{array}$ & $\begin{array}{l}1981 . \\
\text { aug } 31 .\end{array}$ & 37 & na & $1: 1,91$ & na & na & na \\
\hline Pálffy [6] & Bauer & $\begin{array}{l}\text { Egyetemi } \\
\text { neurológiai } \\
\text { klinika }\end{array}$ & Pécs & $\begin{array}{l}1982 . \\
\text { okt. } 1 .\end{array}$ & 57 & na & $1: 1,4$ & na & 30 & na \\
\hline Guseo [7] & Poser & $\begin{array}{l}\text { Megyei } \\
\text { sclerosis } \\
\text { multiplex } \\
\text { centrum }\end{array}$ & $\begin{array}{l}\text { Fejér } \\
\text { megye }\end{array}$ & $\begin{array}{l}1992 . \\
\text { dec. } 31 .\end{array}$ & 78,7 & na & $1: 1,5$ & na & $\begin{array}{l}\text { Férfi: } 32,5 \\
\text { Nő: } 25,9\end{array}$ & $\begin{array}{l}1,92 \\
\text { (1957- } \\
\text { 1991 közt: } \\
1,05-8,02)\end{array}$ \\
\hline $\begin{array}{l}\text { Bencsik, } \\
1998 \text { [9] }\end{array}$ & Poser & $\begin{array}{l}\text { Egyetemi } \\
\text { sclerosis } \\
\text { multiplex } \\
\text { centrum }\end{array}$ & Szeged & $\begin{array}{l}1996 . \\
\text { dec. } 31 .\end{array}$ & 65 & na & $1: 3$ & na & 35 & 7 \\
\hline $\begin{array}{l}\text { Bencsik, } \\
2001[10]\end{array}$ & Poser & $\begin{array}{l}\text { Egyetemi } \\
\text { sclerosis } \\
\text { multiplex } \\
\text { centrum }\end{array}$ & $\begin{array}{l}\text { Csongrád } \\
\text { megye }\end{array}$ & $\begin{array}{l}1999 . \\
\text { júl. } 1 .\end{array}$ & 62 & na & $1: 2,75$ & $\begin{array}{l}\text { ben: } 55 \\
\text { RR: } 36 \\
\text { SP: } 59 \\
\text { PP: } 59\end{array}$ & $\begin{array}{l}\text { ben: } 28 \\
\text { RR: } 28 \\
\text { SP: } 30 \\
\text { PP: } 52\end{array}$ & $\begin{array}{l}\text { Szegeden: } \\
\text { 1997: } 5 \\
\text { 1998: } 6\end{array}$ \\
\hline $\begin{array}{l}\text { Zsiros } \\
{[11]}\end{array}$ & $\begin{array}{l}\text { McDonald } \\
2010\end{array}$ & $\begin{array}{l}\text { Egyetemi } \\
\text { sclerosis } \\
\text { multiplex } \\
\text { centrum }\end{array}$ & $\begin{array}{l}\text { Csongrád } \\
\text { megye }\end{array}$ & $\begin{array}{l}2013 . \\
\text { jan. } 1 .\end{array}$ & 89,8 & $46,6: 128,6$ & $1: 3,08$ & na & $\begin{array}{l}\text { CIS: } 31,4 \\
\text { RR: } 31,7 \\
\text { SP: } 35,4 \\
\text { PP: } 47,3\end{array}$ & na \\
\hline $\begin{array}{l}\text { Biernacki } \\
{[12]}\end{array}$ & $\begin{array}{l}\text { McDonald } \\
2017\end{array}$ & $\begin{array}{l}\text { Egyetemi } \\
\text { sclerosis } \\
\text { multiplex } \\
\text { centrum }\end{array}$ & $\begin{array}{l}\text { Csongrád } \\
\text { megye }\end{array}$ & $\begin{array}{l}2019 . \\
\text { jan. } 1 .\end{array}$ & 105,3 & $56,5: 149,3$ & $1: 2,925$ & $\begin{array}{l}48,83 \\
( \pm 13,23)\end{array}$ & $\begin{array}{l}34,15 \\
( \pm 10,64)\end{array}$ & 4,44 \\
\hline $\begin{array}{l}\text { Iljicsov } \\
{[19]}\end{array}$ & $\begin{array}{l}\text { adminiszt- } \\
\text { ratív } \\
\text { definició }\end{array}$ & $\begin{array}{l}\text { Országos } \\
\text { egészség- } \\
\text { ügyi ellátási } \\
\text { adatok }\end{array}$ & $\begin{array}{l}\text { Magyar- } \\
\text { ország }\end{array}$ & 2015 & 130,8 & $76,8: 179,5$ & $1: 2,6$ & na & na & 2015: 5,4 \\
\hline
\end{tabular}

A prevalencia és az incidencia értékei 100000 fóre értendők.

ben = benignus sclerosis multiplex; CIS = klinikailag izolált szindróma; $\mathrm{F}=$ férfi; $\mathrm{N}=$ nő; $\mathrm{na}=$ nincs adat $; \mathrm{PP}=$ primer progresszív sclerosis multiplex; prev = prevalencia; $\mathrm{RR}$ = relapszáló-remittáló sclerosis multiplex; $\mathrm{SP}$ = szekunder progresszív sclerosis multiplex 
a sclerosis multiplex diagnosztikai kritériumainak módosítása [27-29], amely egyre koraibb fázisban lehetővé teszi a felismerést és a kezelést; a betegek egyre javuló életkilátásai és hosszabb élettartama [22,30]; továbbá a feltételezések szerint bizonyos környezeti hatások is, úgymint a nôk körében egyre gyakoribb dohányzás és obesitas [31], illetve az életmód változásából eredő D-vitamin-hiány [32].

A 2. táblázatban feltüntetett két legfrissebb közlemény 2015-re, illetve 2019-re vonatkozó prevalenciaadatai között látszólag jelentős eltérés van: a 2015-ös országos, adminisztratív adatbázis szerint a nyers prevalencia 130,8/100 000 lakos, míg a Szegedi Tudományegyetem Neurológiai Klinikáján vezetett betegregiszter alapján 2019-ben a nyers prevalencia 105,3/100 000 lakos. E különbség hátterében valószínúleg metodikai okok állnak, például feltételezhető, hogy a hosszú ideje kezelés nélkül tünetmentes, illetve a súlyosan rokkant vagy ágyhoz kötött, idősebb betegek nem jutnak el a regionális egyetemi neurológiai központba, és így nem jelennek meg az ott vezetett adatbázisban (mintavételezési torzítás). Erre indirekt módon utal a viszonylag alacsony átlagos rokkantsági fok (Expanded Disability Status Scale, EDSS: 2,8 pont $\pm 2,44$ ), valamint az immunmoduláns készítményekkel kezelt betegek magas aránya (74,28\%) [12]. Az egészségpénztári adatok elemzésének előnye ezzel szemben az, hogy bármely finanszírozott szakellátó által nyújtott orvos-beteg találkozó rögzítésre kerül. Emellett regionális genetikai jellemzők, illetve egészségügyi ellátási különbségek (a neurológusok száma, hozzáférés a diagnosztikai eszközökhöz) is szerepet játszhatnak a regionális és az országos mutatók közötti különbségben.

A már diagnosztizált, élő betegek átlagéletkora a vizsgált 13 év során lassan, de szignifikánsan emelkedik, mégpedig a nők esetében gyorsabban. A korábbi felmérések közül 2020-ig csak Bencsik és mtsai közöltek erre vonatkozó adatot, mégpedig kórlefolyás szerinti négy betegcsoportra vonatkozóan, amelyek közül a relapszáló-remittáló csoport bizonyult átlagosan a legfiatalabbnak (36 év). Az adminisztratív adatbázisunk alapján számolt átlagéletkor 2015-ben (47,95 év) nagyon jól közelíti a szegedi munkacsoport által publikált 2019-es értéket (48,83 év) [12].

A prevalens betegek koreloszlásának elemzése szerint a legnépesebb korcsoport a fiatalabb életkorúak felé tolódik: kezdetben az ötvenes korosztály képviseltette magát a legnagyobb arányban, majd 2012-től a 35-40 éves korcsoport vált a legnépesebbé.

$\mathrm{Az}$ incidens betegek átlagéletkora évről évre csökken, azaz egyre fiatalabb korban kerül felismerésre a betegség. Az új betegek átlagéletkora 2015-ben 37,4 év volt, a két nem között szignifikáns különbség e tekintetben nem volt. Ez az érték is hasonló a 2019-es Csongrád megyei adathoz, amelynél a prevalens betegek diagnóziskori életkorának átlaga (amely jól közelíti az incidens betegek átlagéletkorát) 34,15 évnek bizonyult [12].
A leírt szignifikáns változások összességében arra engednek következtetni, hogy habár egyre fiatalabbak a sclerosis multiplexszel újonnan diagnosztizált páciensek, és arányaikban egyre többen a harmincas korosztályból kerülnek ki, a jobb túlélés és élettartam miatt egyrészt nő a kórkép prevalenciája, másrészt a teljes betegpopuláció lassan öregszik. Ez az ellentmondás csak látszólagos, hiszen a néhány száz fős, fiatalabb incidens betegcsoport nem kompenzálja a többezres, 50 év feletti és egyre népesebb betegpopuláció emelkedő átlagéletkorát. Vizsgálatunk alapján 2015-ben nagyjából 13000 beteg élt sclerosis multiplexszel Magyarországon, ami 130,8/100 000 nyers prevalenciaértéknek felel meg. Ez magasabb az eddig közölt értékeknél, és további elemzéseket inspirálhat.

\section{Következtetés}

A sclerosis multiplex betegek számát, korösszetételét, földrajzi megoszlását, klinikai jellemzőit, kezelési sikerességét minden egyéb módszernél pontosabban lehetne megítélni egy kötelező, egységes, országos betegregiszter segítségével - amilyet már számos más országban alkalmaznak [33] -, és amelynek tartalmára és szerkezetére nézve már születtek javaslatok $[34,35]$.

Anyagi támogatás: Nemzeti Agykutató Program (20172-1-NKP-2017-00002).

Szerzői munkamegosztás: Adatbázis létrehozása, gondozása: O. F., B. D., A. A. Koncepció: B. D., S. M., I. A. Statisztika: D. B. Szöveg és ábra: B. D., I. A., S. M., D. B., M. D., B. M. A cikk végleges változatát valamenynyi szerző elolvasta és jóváhagyta.

Érdekeltségek: A szerző́knek nincsenek érdekeltségeik a cikkel kapcsolatban.

\section{Köszönetnyilvánítás}

A szerzők köszönik $d r$. Guseo András fóorvosnak a korábbi hazai sclerosis multiplexes felmérésekkel kapcsolatos konzultációját.

\section{Irodalom}

[1] Compston A, Confavreux C. The distribution of multiple sclerosis. In: Compston A, Confavreux C, Lassman H, et al. (eds.) McAlpine's multiple sclerosis. 4th edn. Churchill Livingstone/ Elsevier, Philadelphia, PA, 2005; pp. 71-111.

[2] Wallin MT, Culpepper WJ, Nichols E, et al. Global, regional, and national burden of multiple sclerosis 1990-2016: a systematic analysis for the Global Burden of Disease Study 2016. Lancet Neurol. 2019; 18: 269-285.

[3] Péntek M, Gulácsi L, Rózsa C, et al. Health status and costs of ambulatory patients with multiple sclerosis in Hungary. [Magyarországi sclerosis multiplexes járó betegek egészségi állapota és betegségköltsége.] Ideggyógy Szle. 2012; 65: 316-324.

[4] Lehoczky T, Halasy-Lehoczky M. Multiple sclerosis in Hungary. World Neurol. 1961; 2: 38-44. 
[5] Pálffy Gy. Multiple sclerosis in Hungary, including the Gipsy population. In: Kuroiwa Y, Kurland LT. (eds.) Multiple sclerosis East and West. Kyushu University Press, Fukuoka, 1982; pp. $150-157$

[6] Pálffy Gy. Prevalence of multiple sclerosis in the city of Pécs. [A sclerosis multiplex prevalenciája Pécsett.] Ideggyógy Szle. 1983; 36: 12-17. [Hungarian]

[7] Guseo A, Jófejü E, Kocsis A. Epidemiology of multiple sclerosis in Western Hungary 1957-1992. In: Firnhaber W, Lauer K (eds.). Multiple sclerosis in Europe: an epidemiological update. Leuchtturm-Verlag/LTV Press, Darmstadt, 1994; pp. 279-286.

[8] Guseo A. Multiple sclerosis in Fejér County. Epidemiology, immunology, treatment. [Sclerosis multiplex Fejér megyében. Epidemiológia, immunológia, terápia.] A Veszprémi Akadémiai Bizottság felolvasó ülése: 1992; F/20: 7-21. Available from: http://real-j.mtak.hu/14139/1/MTA_VEAB-FelolvasoUlesei_F20-937124.pdf [accessed: September 30, 2020]. [Hungarian]

[9] Bencsik K, Rajda C, Klivényi P, et al. The prevalence of multiple sclerosis in the Hungarian city of Szeged. Acta Neurol Scand. 1998; 97: 315-319.

[10] Bencsik K, Rajda C, Füvesi J, et al. The prevalence of multiple sclerosis, distribution of clinical forms of the disease and func tional status of patients in Csongrád County, Hungary. Eur Neurol. 2001; 46: 206-209.

[11] Zsiros V, Fricska-Nagy Z, Füvesi J, et al. Prevalence of multiple sclerosis in Csongrád County, Hungary. Acta Neurol Scand. 2014; 130: 277-282.

[12] Biernacki T, Sandi D, Fricska-Nagy Z, et al. Epidemiology of multiple sclerosis in Central Europe, update from Hungary. Brain Behav. 2020; 10: e01598. Doi:10.1002/brb3.1598.

[13] Marrie RA, Yu N, Blanchard J, et al. The rising prevalence and changing age distribution of multiple sclerosis in Manitoba. Neurology 2010; 74: 465-471.

[14] Bezzini D, Policardo L, Meucci G, et al. Prevalence of multiple sclerosis in Tuscany (Central Italy): a study based on validated administrative data. Neuroepidemiology 2016; 46: 37-42.

[15] Roux J, Guilleux A, Lefort M, et al. Use of healthcare services by patients with multiple sclerosis in France over 2010-2015: a nationwide population-based study using health administrative data. Mult Scler J Exp Transl Clin. 2019; 5: 2055217319896090.

[16] Kingwell E, Zhu F, Marrie RA, et al. High incidence and increasing prevalence of multiple sclerosis in British Columbia, Canada: Findings from over two decades (1991-2010). J Neurol. 2015; 262: $2352-2363$

[17] Culpepper WJ 2nd, Ehrmantraut M, Wallin MT, et al. Veterans Health Administration multiple sclerosis surveillance registry: the problem of case-finding from administrative databases. J Rehabil Res Dev. 2006; 43: 17-24.

[18] Culpepper WJ, Marrie RA, Langer-Gould A, et al. Validation of an algorithm for identifying MS cases in administrative health claims datasets. Neurology 2019; 92: e1016-e1028.

[19] Iljicsov A, Milanovich D, Ajtay A, et al. Incidence and prevalence of multiple sclerosis in Hungary based on record linkage of nationwide multiple healthcare administrative data. PLOS ONE 2020; 15: e0236432.

[20] Hungarian Population Census 2011. National data. Available from: http://www.ksh.hu/nepszamlalas/tables_regional_00 [accessed: September 20,2020].
[21] Browne P, Chandraratna D, Angood C, et al. Atlas of multiple sclerosis 2013: a growing global problem with widespread inequity. Neurology 2014; 83: 1022-1024.

[22] Bentzen J, Flachs EM, Stenager E, et al. Prevalence of multiple sclerosis in Denmark 1950-2005. Mult Scler. 2010; 16: 520525.

[23] Mackenzie IS, Morant SV, Bloomfield GA, et al. Incidence and prevalence of multiple sclerosis in the UK 1990-2010: a descriptive study in the General Practice Research Database. J Neurol Neurosurg Psychiatry 2014; 85: 76-84.

[24] Grytten N, Torkildsen $\varnothing$, Myhr KM. Time trends in the incidence and prevalence of multiple sclerosis in Norway during eight decades. Acta Neurol Scand. 2015; 132: 29-36.

[25] Otero-Romero $S$, Roura $P$, Solà J, et al. Increase in the prevalence of multiple sclerosis over a 17 -year period in Osona, Catalonia, Spain. Mult Scler. 2013; 19: 245-248.

[26] Murtonen A, Sumelahti ML. Multiple sclerosis prevalence in 2000 and 2010 in Western Finland. Acta Neurol Scand. 2020; 141: 311-318.

[27] Polman CH, Reingold SC, Edan G, et al. Diagnostic criteria for multiple sclerosis: 2005 revisions to the "McDonald Criteria". Ann Neurol. 2005; 58: 840-846.

[28] Polman CH, Reingold SC, Banwell B, et al. Diagnostic criteria for multiple sclerosis: 2010 revisions to the McDonald criteria. Ann Neurol. 2011; 69: 292-302.

[29] Thompson AJ, Banwell BL, Barkhof F, et al. Diagnosis of multiple sclerosis: 2017 revisions of the McDonald criteria. Lancet Neurol. 2018; 17: 162-173.

[30] Brønnum-Hansen H, Koch-Henriksen N, Stenager E. Trends in survival and cause of death in Danish patients with multiple sclerosis. Brain 2004; 127: 844-850.

[31] Koch-Henriksen N, Thygesen LC, Stenager E, et al. Incidence of MS has increased markedly over six decades in Denmark particularly with late onset and in women. Neurology 2018; 90: 19541963.

[32] Maghzi AH, Ghazavi H, Ahsan M, et al. Increasing female pre ponderance of multiple sclerosis in Isfahan, Iran: a populationbased study. Mult Scler. 2010; 16: 359-361.

[33] Iljicsov A, Simó M, Tegze N, et al. Databases in neurological diseases: overview of international examples in multiple sclerosis. [Nagy adatbázisok neurológiai kórképekben: nemzetközi áttekintés a sclerosis multiplex példáján]. Orv Hetil. 2019; 160: 123-130. [Hungarian]

[34] Bencsik K, Sandi D, Biernacki T, et al. The Multiple Sclerosis Registry of Szeged. [A Szegedi Sclerosis Multiplex Regiszter.] Ideggyógy Szle. 2017; 70: 301-306. [Hungarian]

[35] Iljicsov A, Simó M, Tegze N, et al. Multiple sclerosis in central Hungary: experiences and future possibilities of developing a local database. [Sclerosis multiplex a közép-magyarországi régióban: a helyi adatbázisfejlesztés tapasztalatai és jövőbeli lehetőségei.] Orv Hetil. 2019; 160: 131-137. [Hungarian]

(Bereczki Dániel dr., Budapest, Balassa u. 6., 1083 e-mail: bereczki.daniel@med.semmelweis-univ.hu)

A cikk a Creative Commons Attribution 4.0 International License (https://creativecommons.org/licenses/by/4.0/) feltételei szerint publikált Open Access közlemény, melynek szellemében a cikk bármilyen médiumban szabadon felhasználható, megosztható és újraközölhetö, feltéve, hogy az eredeti szerző és a közlés helye, illetve a CC License linkje és az esetlegesen végrehajtott módositások feltüntetésre kerülnek. (SID_1) 